\title{
Digitalization of Economy and Assessment of Opportunities and Implementation in Agro-Business: World and Domestic Experience
}

\author{
Mnykh Olga, Kostiuk Olha, Dalyk Volodymyr, Zaitseva Anna
}

\begin{abstract}
The article shows the relevance of the implementation of the digitalization policy in the agricultural sector of Ukraine at different levels of government, which is characterized by high losses, regardless of the growth rate. The export-oriented agribusiness sector, which holds a significant share of GDP (15-17\%) and accounts for about $40 \%$ of foreign exchange earnings in total export revenue, has not been able to strengthen its competitive position in international markets serviced by the development of new marketing metrology management and logistics, both for the purpose of improving resource management efficiency and for identifying new sources of value and knowledge based on knowledge in Industry 4.0, Agriculture 4.0.

The limited opportunities for diversification of the development of different types of economic activity and markets in the agricultural sector of Ukraine due to illiterate state economic policy put agrarian management and various related market agents in the face of modern challenges and the need to actively seek adequate responses to dynamic market conditions. The reproduction of the old model of agriculture in Ukraine has aggravated the starting conditions for its development with the increased impact of new globalization challenges at the stage of building Industry 4.0 and the formation of new signs of competition in international markets.
\end{abstract}

\section{INTRODUCTION}

Technical and technological and informational backlog of domestic agricultural production, which occupies a significant share in the GDP structure (15-17\%), provides about $40 \%$ of foreign exchange earnings in total export earnings and has been the main exporter of commodity products for almost 30 years of developing an independent state. This generates new sources of threats in the face of globalization challenges, resulting in deterioration of competitive positions in international markets, loss of business operations and lack of funds to reproduce and improving the quality of life. Food and agriculture industries finished 2017 year at a loss of UAH 1.2 billion, double the amount in 2016 [1], which limits the ability to diversify the development of different types of economic activity and markets to open new sources of creation and the accumulation of added value.

Revised Version Manuscript Received on October 15, 2019.

Mnykh Olga, Department of Marketing and Logistics at Lviv Polytechnic National University, Lviv, Ukraine. (Email: mnykholga1@ukr.net)

Kostiuk Olha, Marketing and Logistics Department at Lviv Polytechnic National University, Lviv, Ukraine.

Dalyk Volodymyr - Department of Management and International Entrepreneurship of Lviv Polytechnic National University, Lviv, Ukraine.

Zaitseva Anna Ukrainian State University of Railway Transport, Kharkiv, Ukraine. (Email: sam934@ukr.net)
The growing uncertainty of the agribusiness market environment in Ukraine and in the world, exacerbated by climate change, the deepening of the environmental, social, financial and food crisis. It puts the agribusiness sector and key managers at the need to develop new features of competitive advantage based on time savings and competencies, covering such as mastering the benefits of artificial intelligence, smart specialization (or smart specialization), developing modern business models that are relevant to trends - Industry 4.0, Logistics 4.0, Agriculture 4.0, arable land enrichment with advanced production technologies with an adequate information support system, etc..

\section{ANALYSIS OF RECENT RESEARCH AND DEVELOPMENT}

In the world, digital transformations and technological innovations have become an important bargain for transactions, in particular in the implementation of an accurate agricultural policy that alters the functional workload of agribusiness models, its own market behavior and potential competitors, stimulating competitive processes, as differentiating processes partial alignment of interests and goals of different market agents [2-5].

The transition to a new stage of information support for agribusiness management systems based on digitalisation of production and economic processes, management decisions and transactions, as shown by world practice, due to certain factors that would force market agents to switch to new agribusiness models and introduce modern communication technologies at the international level with different market structures and end users (type B2B, B2I, B2C). Full control over the implementation of the Digital Order in Ukraine was exercised by the Ministry of Economic Development and Trade (MERT), which acknowledged that the lack of a long-term state strategy was a major problem on the way to build the digital economy [6].

According to economist scientist M. Maciejczak, Poland's agribusiness, ranked 6th among EU countries, must develop on the basis of the food chain and other related industries, thanks to the knowledge gained in innovation [7]. According to the latest McKinsey \& Company report, "Poland as a digital challenge. Digitization as the new engine of growth for the country and the region ", thanks to digitization, the 
Polish economy can grow until 2025 year up to 275 billion zł and to increase its global competitiveness enabling it to become one of Europe's most digitally developed economies [8].

The evolution of agribusiness and interconnected market structures based on the achievements of the NTP entails a critical rethinking of different economic theories: competition, comparative advantage, protectionist policies, socially-oriented and environmental marketing, ecology, systems and systems analysis, free market, value and public value formation [9-11].

\section{AIMS OF THE SCIENTIFIC WORK}

Generalization of the world experience of digitalization and priority directions of research and development of startups in the agrarian sector, identification of the main reasons for the passivity of domestic agribusiness in the processes of digitalization and its lagging behind the growth rate of the Ukrainian IT sector and identification of new opportunities for transformation of the informational sector, where a new foundation of capital accumulation is laid through the digitalization of business processes and management solutions, serving the main purpose of this study.

\section{PRESENTING MAIN MATERIAL}

Although, each farming enterprise is spatially divided, each of them is: a participant in the formation of a culture of economy, development of social and economic process of formation of value and value, in particular, food safety; integrated into the national and international system of statistics and rating comparisons through appropriate indicators of environmental friendliness of agriculture, technologies used, labor productivity, crop yields, developed innovations; the subject and object of agricultural management in a multilevel economy; a market agent in domestic and / or international transactions; buyer and seller of raw materials, finished product and technology, etc. Production, functional-cooperative, logistic and marketing links of each agrarian market participant are the result of economic benefits generated on the market basis. Particularly characteristic of the food industry in Poland and others of the countries after their accession to the EU, there is an opening of new prospects of development of market potential for agribusiness and growth of ties of non-agricultural type (or agreements with different market agents). The last decades of development of agribusiness in the conditions of globalization processes, when large agroholdings and investors intensify export-import operations in industrial, consumer and stock markets (including Ukraine, where land reforms are started and auctions for sale to foreigners and others are actively held, bonds of the domestic government loan - government bonds) are accompanied by:

- developing business practices in related industries and focusing on time management as a competitive advantage in European client-oriented markets;

- the introduction of stringent requirements for environmental friendliness in the agricultural sector and environmental friendliness of food;

- exchange of good management practices in the field of agribusiness;

- technology transfer and commercialization of business ideas with appropriate profitability assessment at each stage of implementation;

- formation of contract logistics principles and marketing control, including: international;

- improvement of information support of farms and their intermediaries;

- forming relationships of type B2B, B2C, B2I, B2Q and enriching the database on the quality of those relationships;

- Creation of CRM and HRM systems that simplify the process of managing relationships with staff, customers and partners;

- obtaining external sources of information through customers and based on market research from markets and competitors;

- combination of activities of agroholdings and others. interested agents in the consumer and stock markets, incl. in Ukraine, especially in 2019, when land reforms begin and auctions for sale to foreigners and others are actively underway. residents of domestic government bonds bonds (T-bills); access to the European stock markets of issuers requires preparation of an appropriate database, ensuring its transparency, training of analysts-brokers, etc .;

- development of modern agribusiness models, adequate opportunities and constraints of the market environment, competitive conditions or conditions of co-operative relations, as a dialectical perspective of the balance of contradictory forces that open up new opportunities for enrichment of knowledge and exchange of experience.

The modern policy of digitization of the economy, which is actively pursued in post-industrial countries, touches all spheres of life of society and every market agent - both agrarian companies and their intermediaries, since saving time and preventive measures to reduce or eliminate unproductive costs should be organically embedded in the system. management at different levels of business management. Digitalization is a new multi-vector process of agro-sector development, where it is possible to strengthen the productive capacity of agriculture and related industries, lay a new foundation of capital accumulation on the basis of digitalization of business processes and management decisions, open new horizons for research by the IT sector of all interested parties (stakeholders).

From improving farm equipment (the first revolution in agriculture) to the emergence of new varieties of seeds and new animal species (the second revolution) to the 1990s (the third revolution), when precision farming, digitization and information technology, radically changing the ratio of labor and capital in the field of agribusiness, including. intellectual, based on new knowledge [12]. In the development of such models are actively involved world startup companies, the priorities of which are shown in Fig. 1.

The international position of the country in the ranking of start-ups of the world depends not only on the number of projects, incl. in the field of agribusiness, but also from the 
quality of those projects and the business environment of the startups, their capacity. At the annual Forbes AgTech Forum, it was named the TOP-25 most innovative start-ups in the agricultural sector, whose intellectual products meet the current challenges of the agricultural management, logistics and marketing of the agricultural sector.

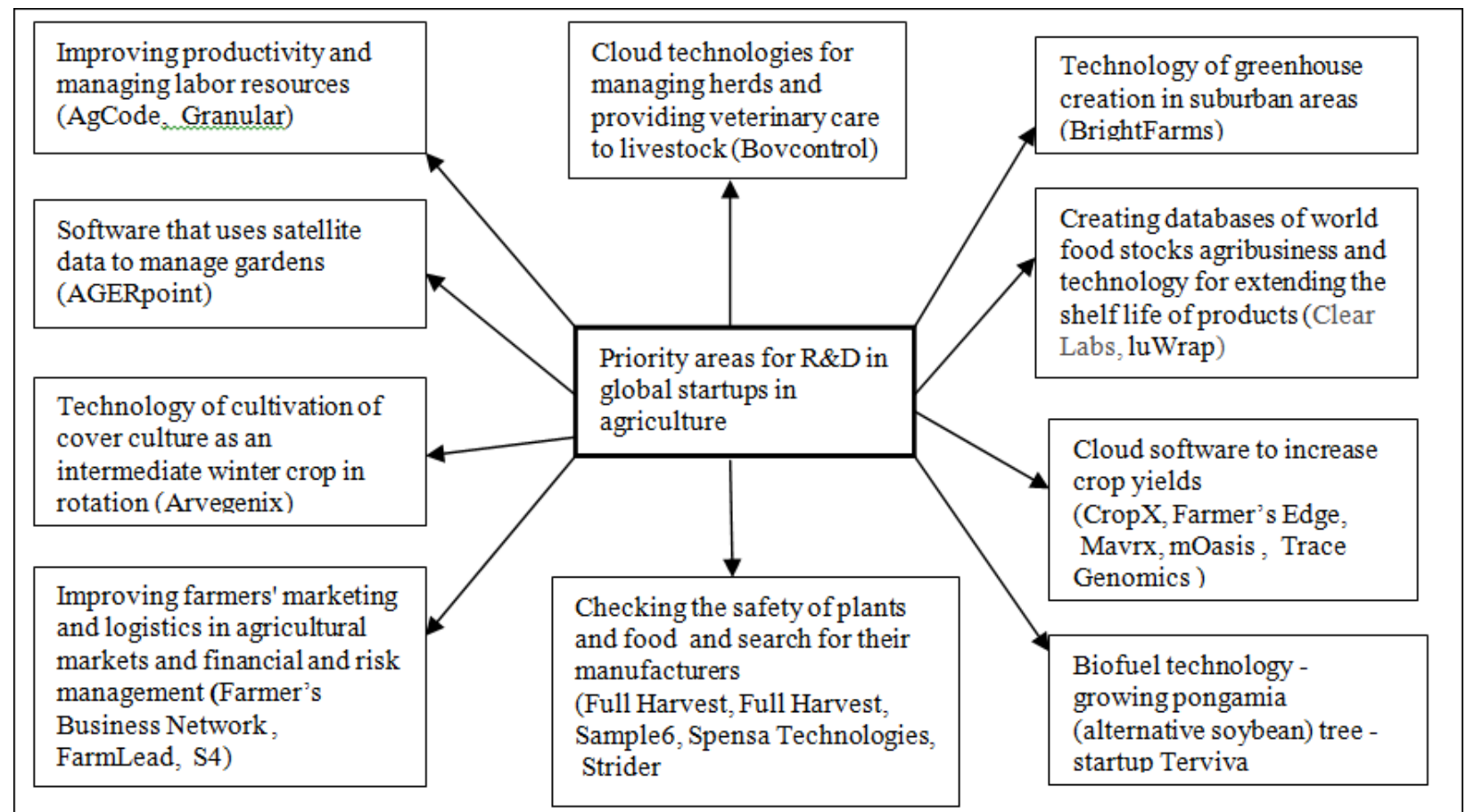

Figure 1. R\&D Priorities for Global Startups in Agricultural and Agrarian Market Research [13]

Thus, R\&D of global startups in the field of agricultural and agricultural market research enrich the potential of innovation in the field of logistics, marketing, management, ecology, sociology, ICT, cartography, and their effective implementation in the practice of business is accompanied by a shift in industry frameworks, economic activities and requires an increase in the competence of users of those intellectual products. The current global market for agricultural IT solutions is estimated by experts to be approximately $\$ 400$ billion annually [14]. Addressing the food and environmental crisis has been the impetus for changing the paradigm of value-oriented management of the agricultural sector, whose participants are involved in all processes of food production.

Introduction to a new phase of agribusiness management called "Agriculture 4.0" in the 21st Century is the automation of processes and business models by combining digital technologies, information and people as technological and digital development make tremendous progress in effective resource management, reduce the negative impact of agriculture and crops on the environment according to the Sustainable Development Goals [15].

In the Global Innovation Ranking for 2017-18. Ukraine was ranked 50th out of 127 countries and significantly lower in the World Digital Competitiveness Rankings - 60th out of 63 countries [16]. The domestic IT sector, because Ukraine in 2018 year was ranked in the Top 35 largest startup countries in the world and 34th place among the 100 countries in the ranking of startup ecosystems [17]. Risks in information security of the economy of Ukraine and agribusiness are accumulated, in particular, due to significant gaps in the technological development of the country (China has transmitted to the Internet 5G since 01.09.19).

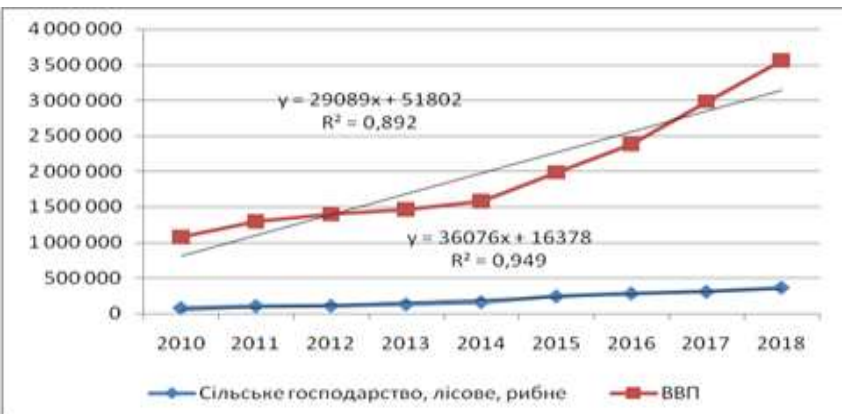

Fig.2 Trends reflecting the change of macro indicators for 2010-18 years, mln.

Built on the basis of: www.ukrstat.gov.ua

Figure 2 shows the constructed trend (t-time factor), which reflects the change of macro indicators in Ukraine for 2010-18. :

$$
\mathrm{Y} 1=51802+29089 \mathrm{t}\left(\mathrm{R}^{2}=0,892\right) ; \mathrm{Y} 2=16378+36076 \mathrm{t}
$$

$\mathrm{y}_{1-}$ GDP, mln. grn; $\mathrm{y}_{2}-$ Agriculture, Forestry and Hunting Sector

$\left(\mathrm{R}^{2}=0,949\right)$.

Despite higher volumes of average annual growth for 2010-18 years income of the Agriculture, Forestry and Hunting sector (by UAH 36 billion at the lower limit of UAH 16.378 billion) compared to GDP growth in general (by UAH 29 billion at the lower limit of 81.8 billion $\mathrm{UAH}$ ), agricultural enterprises do not have a scale effect (or a business scale effect). Geometric average weighted for the growth of the 
above sector in 2010-18 years is amounted to 1,208 , which is an annual increase of $20.8 \%$ annually, but in 2018 years losses of state-owned agricultural enterprises reached UAH 1.3 billion. [], and their accounts payable up to 48 billion UAH. [18]).

The results of the constructed model are obtained on the basis of correlation-regression analysis on the impact of information and telecommunications (X, mln. UAH) on GDP dynamics (U1, mln.) For 2010-18years :

$\mathrm{Y} 1=344796+23.439 \mathrm{X}(\mathrm{R} 2=0.998)$

It shows a positive significant impact of factor $\mathrm{X}$ on $\mathrm{B}$ and high linkage, but such an effect becomes noticeable when GDP is at least 344.796 billion UAH. The trend of information and telecommunications sector dynamics is shown in Fig. 3. From the diffusion of process agro-innovations, accompanied by appropriate information support, including computer, will depend on how to accelerate this trend in the future in the digitalization of the economy.

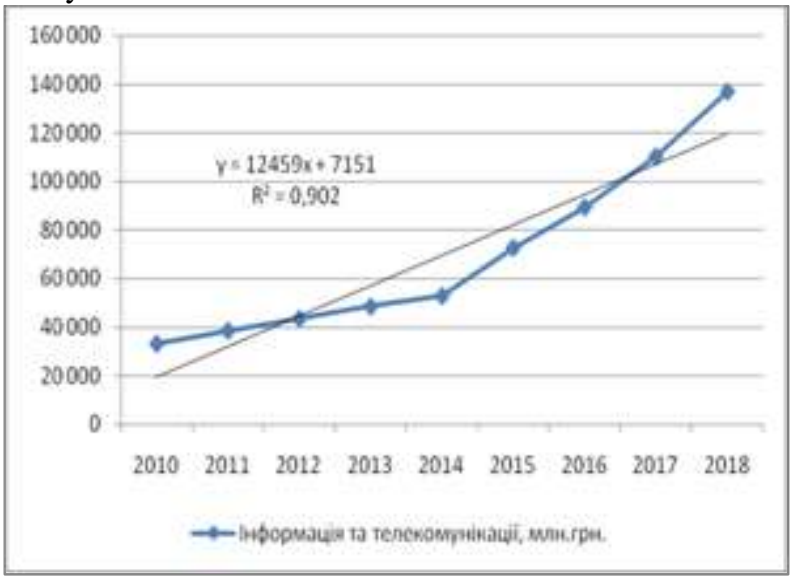

Fig. 3. Economic Growth Trend in the Information and Telecommunications Sector in Ukraine for 2010-18 yeras

Positively fast-growing dynamics in the Information and Telecommunications sector in Ukraine (especially after 2014) have almost bypassed the agricultural sector, where important issues related to communication and Internet access infrastructure in rural, mountainous and rural areas remain unresolved. implementation and integration of digital technologies. The vast majority of agribusiness businesses use invoices in a form that cannot be processed automatically, cannot be digitized.

The reproduction of the old model of agriculture in Ukraine has worsened the starting conditions for its development, with the increased impact of new globalization challenges at the stage of building Industry 4.0 and the formation of new signs of competition in international markets, including Poland, where digitalization has become an important component of the business models of various business and governmental structures and a priority for agribusiness development, organically combined with other areas of innovative development.

The reasons for the economic and innovative lag of agribusiness in the initial stages of its digitalization:

- illiterate state economic and social policy, where agriculture is given the role of exporter of raw materials, which makes it impossible to generate intellectual capital and its systemic resources;

- detachment of agribusiness from other industrial and consumer markets due to contradictory priority goals of development of industries, regions and sectors of the economy, which creates a conflict of interests in the allocation of financial resources, implementation of state support policy for certain regional programs in terms of decentralization of public administration;

- underestimation in the management system of the role of socially oriented marketing, marketing database and information logistics, construction of modern metrological systems at different stages of value added and value creation;

- violation of the state-business-science-society harmonious relations and the state's passive participation as a market agent in the processes of transformation of the agrarian sector of the economy in the direction of building the knowledge economy;

- the absence as such of demand for the intellectual products of domestic startups, incl., in the field of agribusiness, on the part of the farms due to the lack of free cash and the detachment of technological development of the Ukrainian economy from the achieved global results of domestic start-ups;

- the financial benefits of agroholdings due to the undisturbed corruption schemes of export-import transactions for the sale of agricultural products, in the allocation and lease of land, incl. agricultural purpose;

- low level of venture business support due to high investment risks in corruption;

- skepticism of owners of agricultural companies and high concentration of power of individual co-owners in the distribution of share capital, which complicates access to financial information and weakens the possibilities of institutional control by other institutions and legal entities;

- low level of information technology penetration and poor quality of agrarian management in the shadow economy;

- narrowed economic space for the promotion of modern technology and IT at the level of small and medium-sized farms due to lack of available financial resources to acquire foreign innovations;

- imperfection of existing agribusiness models and metrics for assessing its effectiveness due to the lack of a policy of regional specialization at the strategic level;

- dominance of economic policy, focused on more efficient use of traditional factors of production, which makes it impossible for wide cooperation with innovation centers, incl. with start-ups, a business partnership with various stakeholders (stakeholders) to provide new competitive advantages in the face of global challenges;

- insufficient competence of agribusiness workers to develop their own information technologies (their own innovations).

The first Ukrainian Business Innovation Index has started to develop the independent journalistic business resource Mind.ua in partnership with the open innovation platform Re: actor and company KPMG. The domestic IT sector in 2018 year ranked in the Top 35 largest startup countries and 34th place among 100 countries in the ranking of startup ecosystems [20]. 
Although Ukrainian exports of IT products to CEE countries are one of the fastest growing segments of the Ukrainian economy in recent years, with revenues exceeding US \$ 3.6 billion in 2017 year the field of domestic business and management of most farms: in the United States until 2020year. Data analysts forecast the growth by $16 \%$ (according to Daxx, which has development teams in Ukraine, the average annual salary of a Ukrainian developer is $\$ 27,000$, while in the United States - \$90,000, in Switzerland - \$82,000).

Globalization processes in Ukraine have affected the food trade sector to a greater extent, and sectors such as agricultural commodity production and agriculture in Ukraine are characterized by lower levels of globalization and less competitive conditions.

Independent journalist business resource Mind.ua, in partnership with the Re: actor open innovation platform and KPMG in Ukraine, started developing this year's first Ukrainian Business Innovation Index and assessment of the

\section{RESULT AND DISCUSSION}

The long technological backlog of the agricultural sector in Ukraine in terms of digitalization is a consequence of the absence of a state ecosystem development policy, an effective mechanism for smart specialization of regions and public-private partnerships to support innovators, low quality of the institutional environment, in particular, specialized institutions for managing the economy, agricultural sector , science and education. These sectors are detached in terms of both current and strategic development goals and their resources.

It is necessary to create clusters (network economics) based on digital transformation maps in industries with the maximum integration of innovation 4.0 into Ukraine's food security strategy, which requires specific scientific and applied research. Only the development of the domestic manufacturing sector will determine the demand for digital innovations that will transform the prospects of Industry 4.0 and Agriculture 4.0 into the real reality of improving the quality of economic growth. Such an economic model requires the long-term perspective of smart specialization and the formation of a new, strategically minded and responsible political elite, effective interaction between economy, science and business.

\section{REFERENCES}

1. 100 najbi``'shikh derzhkompani`j za ri`k zbi`l`shili pributok majzhe na $40 \%$.- URL: https://www.epravda.com.ua/news/2018/09/28/641097/ Actual information on 2018/09/28.

2. Digitalisierung in der Landwirtschaft: Chancen nutzen Risiken minimieren.- URL: https://www.bmel.de/SharedDocs/Downloads/Broschuer en/DigitalpolitikLandwirtschaft.pdf?_blob=publicationF ile

3. Minister Ardanowski podpisał deklarację o cyfryzacji w rolnictwie.-

URL:

https://www.kalendarzrolnikow.pl/5355/minister-ardano wski-podpisal-deklaracje-o-cyfryzacji-w-rolnictwie Actual information on 2019/10/04

4. Konjunkturbarometer Agribusiness in Deutschland, 2019.impact of high technologies on agribusiness.

https://www.ey.com/Publication/vwLUAssets/ey-konjun kturbarometer-agribusiness-in-deutschland-2019-studie/\$ FILE/ey-konjunkturbarometer-agribusiness-in-deutschlan d-2019-studie.pdf

5. Swobodny przepływ danych - czas na Twój ruch! .- URL: https://www.gov.pl/web/cyfryzacja/swobodny-przeplywdanych--czas-na-twoj-ruch2

6. Czifrova adzhenda Ukrayini - 2020.Proekt.URL:https://ucci.org.ua/uploads/files/58e78ee3c3922.pdf

7. Maciejczak M. Innowacyjność sektora agrobiznesu.URL:http://www.maciejczak.pl/download/innov-agrobiz nes.pdf

8. Bereźnicki J.,Cyfryzacja. Dzięki niej polska gospodarka może wzrosnąć o 275 mld zł do 2025 r..- URL: https://www.money.pl/gospodarka/wiadomosci/artykul/c yfryzacja-dzieki-niej-polska-gospodarka,238,0,2421230. html Actual information on 2018/11/14

9. Uwalniamy cyfrowy potencjał polskiej gospodarki.URL:

https://www.gov.pl/web/cyfryzacja/uwalniamy-cyfrowypotencjal-polskiej-gospodarki

10. Mnykh O.B.,Kostiuk O.S., Sapotnitska N.Ya. Formation and development of innovative economy in the age of business globalization based on implementation of industry 4.0 and logistics 4.0 /Conceptsconomic security at risks: findings from the digitalization of National economy: International Collective monograph / [Edited by: O. Vlasiuk, O. Ilyash, M. Osinska]. - Vol. 5. Bydgoszcz, Poland: University of Economy in Bydgoszcz, Publishing House, 2019. - P. 129-156

11. Landwirtschaft und Digitalisierung.- URL: https://www.schaumann-stiftung.de/cps/schaumann-stiftu ng/ds_doc/27_huelsenberger_gespraeche_broschuere.pdf

12. Jak cyfryzacja wpływa na prace polskich rolników? .URL:

https://agronews.com.pl/artykul/jak-cyfryzacja-wplywa-n a-prace-polskich-rolnikow/ Actual information on 2019/01/02

13. TOP-25 najbi'l'sh i`nnovaczi’jnikh startapi`v u si'l`s`komu gospodarstvi za versi yeyu Forbes.- URL: https://propozitsiya.com/ua/top-25-naybilsh-innovaciyny h-startapiv-u-silskomu-gospodarstvi-za-versiyeyu-forbes

14. IT dlya agrari yiv:yak zarobiti na tekhnologi yakh u si'l's`komu gospodarstvi - bi`znes-plan.- URL: https://hromadske.ua/posts/it-ahrarii-tekhnolohii-silske-h ospodarstvo

15. Gandorfer M., Schleicher S, Heuser S. Landwirtschaft 4.0 - Digitalisierung und ihre Herausforderungen.- URL: https://www.lfl.bayern.de/mam/cms07/ilt/dateien/digitali sierung_und_ihre_herausforderungen.pdf

16. Ukrayina pi `nyalasya $\mathrm{v}$ rejtingu czifrovoyi konkurentospromozhnosti .- $\quad$ URL: https://www.epravda.com.ua/news/2018/06/20/637985/A ctual information on $2018 / 06 / 20$

17. Ukrayina potrapila $\mathrm{v}$ top-35 najbi`l`shikh startap-krayin svi tu.URL: https://business.ua/news/4920-ukraina-potrapyla-v-top35 -naibilshykh-startapkrain-svitu Actual information on 2019/04/16

18. Oczi`neno zbitki derzhavnikh agrokompani`j za 2018 ri'k.URL: https://agropolit.com/news/14044-otsineno-zbitki-derjav nih-agrokompaniy-za-2018-rik

19. I'nnovaczi yi ta APK: chomu za takim soyuzom majbutnye.-

URL: https://mind.ua/publications/20202576-innovaciyi-ta-apk -chomu-za-takim-soyuzom-majbutne 
20. Ukrayina posi la 35 mi`scze u rejtingu startap-krayin svi tu - $\quad$ Startup Blink.- URL: https://impactlab.media/2019/04/16/ukrayina-35-mistse-u -reytingu/

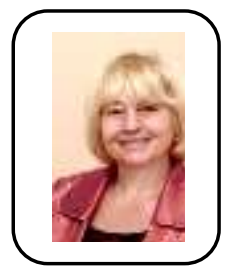

\section{AUTHORS PROFILE}

Mnykh Olga, Doctor of Economics, Professor at the Department of Marketing and Logistics at Lviv Polytechnic National University, where she has been working since 2002. In November 2009 she defended her doctoral dissertation, in 2010. received her Doctor of Economics diploma and the rank of Professor. Author of more than 400 scientific papers in domestic and foreign professional publications. Full member of the Academy of Economic Sciences of Ukraine, awarded with the badge of the Ministry of Education of Ukraine "Excellence in Education".

Main topics of research: financial and marketing aspects of value formation, economic and mathematical modeling of business processes and marketing, international marketing

https://orcid.org/0000-0003-0219-0533

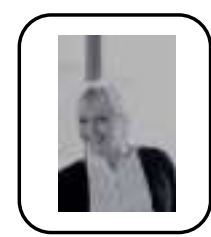

Kostiuk Olha, Ph.D., Assoc.Prof.,Associate Professor of Marketing and Logistics Department at Lviv Polytechnic National University, where she has been working since 2003. In October 2008, she defended her $\mathrm{PhD}$ thesis and in 2009 received her $\mathrm{PhD}$ in Economics and an associate professor's title. Author of professional editions. more than 100 scientific papers in domestic and foreign

The main topics of research are marketing and logistics strategies, digital technologies in marketing and logistics.

https://orcid.org/0000-0002-3499-2787v

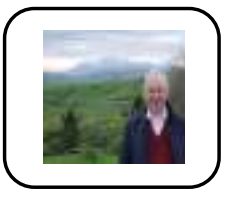

Dalyk Volodymyr - Candidate of Sciences (Economics), Associate Professor at the Department of Management and International Entrepreneurship of Lviv Polytechnic National University. Has been working at the university since 2007. It combines scientific-pedagogical activity with entrepreneurial activity. Author of more than 100 scientific articles.

The main topics of research are business theory and practice, international entrepreneurship

https://orcid.org/0000-0002-7610-3319

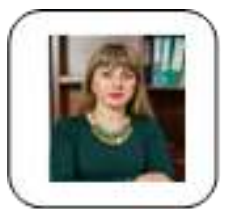

Zaitseva Anna graduated from the Ukrainian State University of Railway Transport with a major in Enterprise Economics in 2014. She has published more than 30 scientific papers, including 2 articles in a journal indexed by Web of Science. Scientific interests are focused on economics and national economy management and international logistics.

https://orcid.org/0000-0003-0818-7853 